Proceedings of the 2nd international conference Economic and Business Trends Shaping the Future | 2021

\title{
ORGANIZATIONAL CHANGE AND EMPLOYEE STRESS: EMPIRICAL ANALYSIS OF EMPLOYEES IN THE REPUBLIC OF NORTH MACEDONIA
}

\author{
Andrijana Ristovska \\ National Bank of the Republic of North Macedonia \\ andrijanaristovska07@yahoo.com \\ Ljupco Eftimov \\ Faculty of Economics - Skopje, Ss Cyril and Methodius University \\ eftimov@eccf.ukim.edu.mk
}

\begin{abstract}
This paper addresses the issue of the importance and necessity of introducing constant organizational changes and their impact on employee stress as one of the primary pull factors of the employee turnover intention. In this regard, human resource managers in organizations are becoming increasingly aware that hiring and retaining talents are the most important determinants of success in the complex global world and that they must work more intensively on modernizing the process of change management to help employees, not only for acceptance, but also for their involvement in the change implementation process.

The number of respondents from the processed data so far is 439 employees (differing according to their demographic characteristics).

The purpose of this paper is to determine whether there is a statistically significant difference between the four different types of organizational change according to the Cummings and Worley (2014) organizational change classification (Human process changes; Techno-structural changes; Human resource management changes and Strategic changes), regarding their impact on the employee emotional state, as well as which type of organizational change has the most significant impact on employee stress in the Republic of North Macedonia.

The survey findings contributed to the conclusion that Macedonian employees in terms of their feelings of fear, anxiety, nervousness, etc., equally perceive the impact of the different types of organizational change. More specifically, there are no statistically significant differences between the impacts of the different types of organizational change over the stress they face because of these changes.
\end{abstract}

Key words: organizational change; human process changes; techno-structural changes; human resource management changes; strategic changes; stress; employee' turnover intention.

JEL Classification: C83, C88, J63, O33, 131

http://hdl.handle.net/20.500.12188/15856

http://doi.org/10.47063/EBTSF.2021.0001 


\section{INTRODUCTION}

Throughout its existence, man is constantly learning new mechanisms of adaptation or counteraction to unwanted changes, which affect him and his growth by drawing positive outcomes from the decisions made, both in private and professional life. Changes in professional life have a strong impact on private life, and vice versa, in a continuous paradigm that strives to achieve an acceptable balance.

Change is an integral and inevitable part of organizations as well, because their sustainability and development is strongly influenced by the process of change and transformation (Rothwell et.al; 2016; p.4). The degree of acceptance of the organizational change or the development of greater or lesser resistance, which is manifested in the employee behavior, also depends on the manner of implementation of the organizational change.

Successful implementation of organizational change is possible. The changes do not only refer to a new location, new processes, new structures, level of performance, but in essence, they represent a simultaneous raising of the organization's ability to deal with and respond to emerging needs, opportunities and impacts. In organizational systems people are making strong efforts in the processes of change and they are becoming more and more attached to it. They are having more confidence in their own contributions and a higher level of readiness to deal with future changes, by continuously building experience in these processes. Organizational change occurs when the process of transition from the current status quo to another desired future state begins. This process is actually based on planning and implementing change, in a way that will achieve the lowest level of employee resistance, as well as the lowest organizational costs, but at the same time realizing the maximum level of change implementation effectiveness. Change and its impact is one of the most widely discussed issues in the field of contemporary management. In today's business environment, organizations must constantly make changes in order to remain competitive in the global market (Sikdar; Payyazhi; 2014).

Regardless of its type, change needs to be properly managed and implemented as it has a strong impact on improving the level of costs, quality, decision-making process and the entire management process in general (Van Hoek et al.; 2010). According to Christiansen and Claus (2015), it creates a domino effect in all other aspects of the organization and their overall improvement. On the other hand, improper change management creates negative effects, which often lead to the loss of significant resources, both in terms of time and finances, as well as people and their effort and energy. Hence, it not only leads to unsuccessful implementation of change, but also restores the organization to its previous state, from which it will be very difficult to recover again (Simoes; Esposito; 2014).

The most critical reason why efforts to bring about organizational change fail is the employee resistance. Change is often experienced with fear which makes it difficult to implement it, as organizations find it very difficult to obtain the necessary support and commitment from employees. In this regard, the ability to effectively manage change is a much-needed skill that managers need to possess, because organizations need people who will have a strong and significant positive contribution to change efforts. Employee resistance often occurs as a result of fear of losing their job or their status in the organization, and this happens precisely because of the lack of understanding of the purpose and need for change, which is actually a result of lack of the ability to effectively manage change, or it happens simply because people have different views and perspectives on change than those of management. For these reasons, it is already common that people oppose change, while the organizations lack real people who will move the organization from the current to the new state. Instead, organizations are flooded with employees 
who do not take serious enough effort and responsibility because they feel too dependent. However, the high level of awareness and ability to look through the prism of other employees, their involvement in the process of planning change and continuous knowledge sharing and utilization, increases the likelihood and possibility of successful implementation of organizational change.

The global team of change fanatics and advocates of Prosci, Inc., define change management as "the application of a structured process and set of tools for leading the people side of change to achieve a desired outcome". Effective change management means starting the process at the initial stage of change planning and accurately defining and determining the desired and required result. Cummings and Worley (2014), in their book "Organizational Development and Change", identify four key types of organizational change, or as they call it, interventions:

1. Human process changes

2. Techno-structural changes

3. Human resource management changes

4. Strategic changes

A number of studies have been conducted showing the effect of organizational change on employee stress and the mediating role of stress, which as a consequence of organizational changes, can lead to encouraging the employee turnover intention (Enshassi et al.; 2015; Strutton, Tran; 2014; Thunman; 2015). Stress is a very critical factor that has lasting effect on employee intention to leave (Nguyen et al.; 2012). This intention is amplified if the organization is going through a process of change (Smollan; 2015). Ghosh et al. (2013). Tjemkes and Furrer (2010) accepted stress as a mediator in case of interventions related to human processes. It is stress that ultimately forces employees to leave rather the human process change in itself (Krell; 2012). Different researchers have identified the role of stress in the form of mediation consequent of different type of organizational changes (Slåtten et al.; 2011; Riot, de la Burgade; 2012). Enshassi et al. (2015) and Hede (2010) in their research identified the role of stress in techno structural interventions being brought in the organization. Stress kills the creativity of the organization and if not handled properly can force employees to quit (Vithessonthi, Thoumrungroje; 2011). Wong et al. (2015); Li and Zhou (2013) and Johannsdottir et al. (2015) validated stress in mediating role in cases of human resource interventions. They were of the view that change in human resources and its policies send employees on back foot and reinforces employee's turnover intention. If changes are made to strategies employee face stress that ultimately leads to turnover intentions (Farler, Broady; 2012; Tuzun, Kalemci; 2012; Yuan et al.; 2014).

The subject of this paper covers extensive theoretical knowledge of the organizational change concept, its necessity in contemporary organizations and the need for its proper management, but also practical knowledge in terms of the impact of different types of organizational change on employee stress in the organization, as a factor that is seriously influenced by any emerging condition.

The purpose of this paper is to determine whether there is a statistically significant difference between the four different types of organizational change according to the Cummings and Worley (2014) organizational change classification (Human process changes; Techno-structural changes; Human resource management changes and Strategic changes), regarding their impact on the employee emotional state, as well as which type of organizational change has the most significant impact on employee stress in the Republic of North Macedonia. Employee stress is an extremely important issue for which organizations, and especially their human resource management, need to make serious efforts to reduce it and manage it properly. Otherwise, it can lead to serious 
consequences, such as encouraging the employee intention to leave the workplace, ie, dysfunctional fluctuation (Raza et.al.; 2017; p.4).

\section{THEORY REVIEW}

In the literature, changes are often identified with the term "interventions". The very term "intervention" refers to a system consisting of a series of planned actions or events, designed to facilitate the process of increasing the organizational effectiveness. Interventions are intentional attempts to direct an organization to a different and more effective situation that tend to disrupt its status quo.

Organizational development includes three important criteria as fundamentals that define the effective organizational intervention: (1) the extent to which it is harmonized with the organizational needs; (2) the extent to which it is based on causal knowledge of the expected outcomes; and (3) the extent to which it delegates responsibility for managing change to organizational members. The success of organizational intervention strongly depends on the readiness of the organization for the planned change. The indicators of change readiness include sensitivity to the pressures of change, dissatisfaction with the status quo, the availability of resources to support change, and investing significant time in managing change. Once these conditions are in place, interventions can be designed to address the organizational issues identified in the diagnostic process. When preparedness for change is relatively low, interventions need to be focused precisely on increasing it (Cummings; Worley; 2009; p.3).

The change effects are great and numerous. One of the most significant effects is increased stress on individuals, employees, and their families. By increasing the level of change, people struggle to maintain their own level of emotionality and cognition. Feelings of stress as a result of the change, if strongly expressed, can lead to serious deviant behaviors, such as increased use of alcohol, drugs, violence at work, domestic violence, suicide, but also create a number of health disorders, such as heart disease, chronic disease and many other extremes (Magyar; 2003). Stress can also provoke anger in the workplace, increased interest in developing work-life balance programs, and even encouraging people to seek innovative solutions and ways of working that will distance them from others (Rothwell et al. al .; 2016; p.6).

The introduction of change processes and their implementation in organizations creates a sense of anxiety, uncertainty, fear and stress (Ronnenberg et al.; 2011). Therefore, the responsibility for managing and monitoring the employees during this process belongs to the so-called "change agents", and these are actually people, inside or outside the organization, who are able to help the organization in the process of transformation and to achieve greater effectiveness and development. Their role is to facilitate the implementation of change. Most often, as the most common initiators of change, but also due to the fact that they have the necessary authority to influence the attitudes of their employees, managers act as change agents. Thus, management must be persistent, realistic, to set clear goals and have strong attitudes, to possess the ability to achieve the set goals and a high level of empathy, as well as a strong sense of understanding others, in order to properly explain its employees the need for change. If employees do not understand the change process and the necessity for its implementation, that will definitely increase their level of stress (Abrell-Vogel; Rowold; 2014). If this state is not further properly taken into account, regarding the use of appropriate steps and programs for stress management, as well as improving the way employees are guided through this process, the end effect may be leaving the organization. This will not only affects the process of change, but also would have a negative impact on organizational performance (Rusly et al.; 2012). Therefore, in the overall process of organizational 
development, the role of human resource management is critical. According to Cummings and Worley (2014) "the function of human resource management is to provide change management skills through traditional training programs, rather than through the work based learning process, which proves to be an extremely effective way of organizing development". Hence, human resource management must work more intensively on modernizing the process of change management and continuous implementation of strategies to help employees, not only for acceptance, but also for their involvement in the creative and practical process of implementing organizational changes.

Stress is one of the most critical factors that has a lasting effect on employee turnover intention. This intention gains more strength if the organization goes through a process of change (Smollan; 2015).

Human process changes, or interventions, help employees understand the communication protocols that take place in each organization (Bull; Brown; 2012). Employees are more prone to conflict if appropriate mechanisms for interaction at the individual level are not identified (Perrott; 2011). If the employees in an organization are not able to communicate properly on an individual level, the likelihood of conflict is higher, and therefore, changes related to the processes of human resources are necessary (Szabla et al. 2014; Worch et al.2012 ). It often happens that employees do not understand the reasons for implementing this type of change. This creates stress and encourages their turnover intention (Tsai, Tien; 2011; Carlström; 2012). Therefore, it is of particular importance to provide, not only adequate communication, but also a detailed and objective justification and clarification of the reasons for the introduction of change processes.

The organizational structure plays a very important role in the functioning of the organization. Due to the different types of organizational structure, organizations often need to change it. If they feel that it is necessary to improve and change the existing organizational structure, and that their structure does not meet the set goals and requirements, they must go through the process of techno-structural interventions, ie, changes (Rahman, Nas; 2013). However, the process of introducing techno-structural changes is by no means a simple process (Davenport et al.; 2004). One of the main effects of these changes is the redistribution of resources and authority (Wang; 2014; Chen et.al.; 2014). This type of change can often create a sense of loss of power or resources for certain groups of employees and as a result, they will resist these interventions (Dysvik, Kuvaas; 2010). Techno-structural changes are also a source of change in the level of involvement of employees in the organization (Stensaker et al.; 2014). Nyström et.al. (2013) identify the importance of techno-structural changes and their impact on the level of employee empowerment. Employees feel overwhelmed if they are not capable, or are not able to understand all the details related to the change process. As a result, employees try to remove all doubts and ambiguities by justifying the need for change, or by leaving the organization (Aladwan et al.; 2014).

Through their own professional experience in the workplace, employees adapt to established human resource policies in the organization (Li, Zhou; 2013). Therefore, whenever certain policy-related changes are planned, employees have a different perception from the one that is essential and realistic, and as a result, they experience a sense of unnecessary stress (Enshassi et al.; 2015). If employees believe that human resources management changes will have a negative impact on them, this perception will continue throughout the overall process of change (Björklund; 2010).

Finally, strategy is defined as the foundation, the pillar of an organization. From all aspects in each organization, it is the strategies that are most strongly established and embedded in the perception 
and acceptance of employees (Tuzun, Kalemci; 2012), because they define and determine the way of their work. Thus, strategic changes create transformational changes that affect the overall operation of organizations (Bhatnagar et al.; 2010). Employees who are part of an organization that introduces continuous change should be able to handle continuous pressure. Organizations that are focused on a strategy of continuous improvement, must focus on building the ability and capacity of employees to deal with the stress that comes as a result of these processes. Otherwise, unsuccessful management of this process encourages employees to consider leaving the organization (Nguyenetal; 2012a).

\section{METHODOLOGY}

The following methods were used in order to achieve the objectives of this paper: descriptive method, historical method, methods of analysis and synthesis, comparative method, quantitative and statistical method and methods of induction and deduction. A survey questionnaire was used as a instrument for data collection, which was conducted in the period November-December 2020. The target group of respondents included in the survey were employees from different sectors (public sector, private sector, non-profit organization) in the Republic of North Macedonia, namely, a random sample of $\mathbf{5 0 0}$ respondents with different demographic characteristics, of which 282 respondents completely answered the survey questionnaire. The questions in the survey questionnaire, which in addition to the scope of questions to determine demographic characteristics (gender, age, education, type of education, type of studies, sector, type of contract, length of service, previous work experience, turnover reasons, etc.), also contain questions to determine the condition of employees in relation to their attitudes and opinions based on questions about their job satisfaction, the impact of organizational change on their stress, as well as questions to determine their turnover intention. This survey questionnaire is, in fact, an adapted combination of three published international questionnaires, namely the PIAAC (Program for the International Assessment of Adult Competencies), the Employee Resistance Assessment Questionnaire (Oreg; 2003) and the Turnover Intention Assessment Questionnaire (Van Dam; 2008). For the purposes of this paper, this questionnaire will help in determining the impact of different types of organizational change, the so-called interventions in the organization, as part of organizational development, as follows: human process changes; techno-structural changes; human resource management changes and strategic changes on employee stress. The questionnaire was conducted through the electronic service for collection and analysis of research data "Kwik Surveys", as well as sent electronically (via e-mail and social networks) to the respondents.

The subject of this paper covers extensive theoretical knowledge of the organizational change concept, its necessity in contemporary organizations and the need for its proper management, but also practical knowledge in terms of the impact of different types of organizational change on employee stress in the organization, as a factor that is seriously influenced by any emerging condition.

The purpose of this paper is to determine whether there is a statistically significant difference between the four different types of organizational change according to the Cummings and Worley (2014) organizational change classification (Human process changes; Techno-structural changes; Human resource management changes and Strategic changes), regarding their impact on the employee emotional state, as well as which type of organizational change has the most significant impact on employee stress in the Republic of North Macedonia. 
The following hypotheses are proposed in order to investigate the set subject and problem in this paper:

Hypothesis 1: By comparing the mean values, there are statistically significant differences between the impacts of human process changes and techno-structural changes on stress.

Hypothesis 2: By comparing the mean values, there are statistically significant differences between the impacts of human process changes and human resource management changes on stress.

Hypothesis 3: By comparing the mean values, there are statistically significant differences between the impacts of human process changes and strategic changes on stress.

Regarding the methodological approach used, the hypotheses are tested using a statistical Ztest. In this paper, the Z-test is used to determine whether there is a significant difference between the impact of human process changes on stress and the impact of other types of organizational change on stress. The higher the value of $Z$, the greater the difference between the mean values of the two samples. If the testing confirms statistically significant differences, then the research hypotheses can be accepted and further statistical testing will be performed in order to reveal the type of organizational change that has the greatest impact on stress. If testing confirms that there are no statistically significant differences between the impacts of human process changes and the other types of organizational change on stress, it can be concluded that the mean values of all organizational changes are the same.

Namely, when the test statistic is greater than the corresponding critical value, for a given level of significance $\alpha$, ie, when the p-value is less than $\alpha(p<\alpha)$, we can say that there are statistically significant differences between the data. In that case, the null hypothesis is rejected. Typically, the significance level $\alpha=0.05$ is used as the standard for such tests.

The statistical analysis of the research results and the graphical presentation of the results are presented in MS Excel.

\section{RESEARCH FINDINGS}

The findings of the employees' demographic characteristics (gender, age, educational structure, sector and length of service), as well as the analysis of the impact of different types of organizational change on employee stress are presented below. The latter are ranked on a Likert scale of $1-10$, according to the degree of their impact.

Distribution of respondents according to their demographic characteristics results in the following findings:

Gender: Domination of female respondents (66\%), compared to male respondents (34\%);

Age: $38 \%$ are at the age of $26-35$, followed by $24 \%$ respondents at the age of $36-45,24 \%$ from $46-55$ years, $9 \%$ from $18-25$ years and $6 \%$ over 55 years.

Education level: $59 \%$ of the respondents are with higher education, $25 \%$ have master's degree, $12 \%$ have completed secondary education and only $4 \%$ have doctorate degree.

Sector: $56 \%$ of the respondents are employed in the public sector, $40 \%$ are employed in the private sector, while $4 \%$ in a non-profit organization.

Length of service: $38 \%$ are engaged for more than 10 years, $25 \%$ for $1-3$ years, $14 \%$ for less than 1 year, $13 \%$ for $4-6$ years and $10 \%$ for $7-10$ years.

Numerous studies have shown that demographic characteristics affect respondents' perceptions about the introduction of organizational change, as well as the degree of impact of those changes 
on their feeling of stress. In order to meet its purpose, this paper's main focus is to analyze the impact of the organizational change on employee stress, as well as whether there is a statistically significant difference between the four types of organizational change and to determine the type of change that has the most significant impact on stress of the employees in the Republic of North Macedonia.

The hypotheses and the conducted $\mathbf{Z}$ tests are presented below (Figure 1-3):

Ho hypothesis: By comparing the mean values, there are not statistically significant differences between the impacts of human process changes and techno-structural changes on stress.

$H_{1}$ hypothesis: By comparing the mean values, there are statistically significant differences between the impacts of human process changes and techno-structural changes on stress.

Figure 1: Z-test result

\begin{tabular}{|l|r|r|}
\hline & Variable 1 & Variable 2 \\
\hline Mean & 5.34 & 4.85 \\
\hline Stdev & 15.02 & 16.92 \\
\hline Observations & 439 & 439 \\
\hline$Z$ Stat & 0.41 & \\
\hline$p$ value & 0.69 & \\
\hline$Z$ Critical & 1.96 & \\
\hline \multicolumn{2}{|c|}{ Source: Illustration by the author } \\
\hline
\end{tabular}

First, when applying the Z-test, the obtained $p$ value (0.69) is compared with the value of $\alpha(0.05)$. In this case, 0.69> 0.05, whereby the null hypothesis is accepted. The same conclusion is confirmed by comparing the realized value of the $Z$ test with the critical value. In this case, the realized value of 0.41 is less than the critical value of 1.96 , which means that the research hypothesis $\left(\mathrm{H}_{1}\right)$ is rejected.

Ho hypothesis: By comparing the mean values, there are not statistically significant differences between the impacts of human process changes and human resrouce management changes on stress.

H1 $_{1}$ hypothesis: By comparing the mean values, there are statistically significant differences between the impacts of human process changes and human resrouce management changes on stress.

Figure 2: Z-test result

\begin{tabular}{|l|r|r|}
\hline & Variable 1 & Variable 3 \\
\hline Mean & 5.34 & 4.77 \\
\hline Stdev & 15.02 & 14.01 \\
\hline Observations & 439 & 439 \\
\hline$Z$ Stat & 0.52 & \\
\hline$p$ value & 0.60 & \\
\hline$Z$ Critical & 1.96 & \\
\hline \multicolumn{2}{|c|}{ Source: Illustration by the author } \\
\hline
\end{tabular}


Based on the result of the conducted $\mathrm{Z}$ test, in this case the second research hypothesis $(\mathrm{H} 1)$ is rejected, ie the null hypothesis is accepted, because the $\mathbf{p}$-value $=\mathbf{0 . 6 0}$, and it is greater than the value of $\alpha \mathbf{( 0 . 0 5 )}$, while the realized value of the $Z$ test is 0.52 , which is less than the critical value of 1.96 .

Ho hypothesis: By comparing the mean values, there are not statistically significant differences between the impacts of human process changes and strategic changes on stress.

$\mathbf{H}_{1}$ hypothesis: By comparing the mean values, there are statistically significant differences between the impacts of human process changes and strategic changes on stress.

Figure 3: Z-test result

\begin{tabular}{|l|r|r|}
\hline & Variable 1 & Variable 4 \\
\hline Mean & 5.34 & 5.07 \\
\hline Stdev & 15.02 & 13.3 \\
\hline Observations & 439 & 439 \\
\hline$Z$ Stat & 0.25 & \\
\hline$p$ value & 0.80 & \\
\hline$Z$ Critical & \multicolumn{2}{|c|}{1.96} \\
\hline \multicolumn{2}{|c|}{ Source: Illustration by the author } \\
\hline
\end{tabular}

Regarding the testing of the third research hypothesis, the $Z$ test also finds that there are no statistically significant differences between the impacts of human process changes and strategic changes on stress, as in this case $\mathrm{p}>\alpha(0.80>0.05)$. Therefore, the third research hypothesis is rejected.

Based on the conducted testing, none of the three research (alternative) hypotheses is accepted and it is concluded that the impact of all types of organizational change on stress is equal, ie, no impact of a certain type of change deviates significantly from the impact of any other type.

\section{DISCUSSION AND CONCLUSION}

The purpose of this paper is to determine whether there is a statistically significant difference between the four different types of organizational change according to the Cummings and Worley (2014) organizational change classification (Human process changes; Techno-structural changes; Human resource management changes and Strategic changes), regarding their impact on the employee emotional state, as well as which type of organizational change has the most significant impact on employee stress in the Republic of North Macedonia.

This paper identifies four types of organizational change using the theoretical assumptions of Cummings and Worley (2014), Rothwell et.al. (2016), Oreg (2003), and Raza (2017), as well as numerous theories and contemporary research on organizational development and organizational change. Each type of organizational change covers a number of interventions that correspond to the appropriate type, which the respondents ranked on a Likert scale of 1-10 according to the degree of their impact on the employee feeling of stress. These changes, or, the so-called interventions are: human process changes, techno-structural changes, human resource management changes and strategic changes.

Through the use of practical examples from around the world and extensive theory in the field of organizational change, as well as human resource management, it has been established that if 
employees fail to understand the change process and are left unattended during the change process, it would result in employees feeling stressed (Abrell-Vogel and Rowold 2014) which if not properly taken into account, it may ultimately result in employees leaving the organization. Employees who are part of an organization that introduces continuous change should be able to cope with continuous pressure. Organizations that are focused on continuous improvement, must focus on strenghtening the employee ability and capacity to deal with stress that comes as a result of these processes. Otherwise, failing to manage this process encourages employees to consider leaving the organization.

Using the Z-test to determine the existence of statistically significant differences between the impacts of different groups of changes on employee stress in the Republic of North Macedonia, it was found that at the level of the overall sample, no impact of a particular group of changes deviates significantly from the impact of any other group of changes. In this regard therefore, it can be concluded from this point that none of the three hypotheses is accepted and that the impact of all changes on stress is equal.

Attempts by organizations to introduce changes in human resource policy increase the feeling of stress among employees. This is due to the fact that human resource policies are the basis on which employees communicate with organizations. Issues related to the promotion, development and training of employees depend on the human resource policies of the organizations. Consequently, when management decides to make a change in these policies, employee stress increases as a result of their fear that the change may adversely affect their status, power, function, etc. Hence, in order to reduce employee stress level, change agents and management must ensure that change will not adversely affect employees.

Human process changes (change in communication, functioning, group norms and rules) also increase the level of employee stress. Therefore, it is necessary for the organizations to make sure that the employees are informed in time about the intention and the plan for change, as well as to be involved in its creation and implementation, which would increase their motivation for acceptance, but also their trust. Techno-structural interventions also create fear and suspicion among employees. Hierarchy plays a very important and influential role in the way employees work. According to Worch et. al. (2012), the involvement of employees in techno-structural changes reduces their feeling of stress and consequently reduces the risk of eventual stimulation of their turnover intention. Finally, strategic changes also affect stress. Strategies are created and implemented at the top management level, but they have a strong impact on both group and individual level.

Hence, human resource management in organizations should manage change from all aspects and to be involved in managing all types of organizational change. Regardless of the type of organizational change, employees respond equally and develop similar manifestations of stress that can be critical to their health and abstinence, or, ultimately lead to turnover. In order for the organization not to face the consequences of turnover, the preventive role consists in preparing for organizational change through strategies and tactics that will correspond to the type of organizational change.

These findings can be used in local and international context. In macedonian context, this research can help organizations in implementing change effectively, developing change interventions and understanding their connection with employee stress. Change agents can make use of it to develop change interventions and deal with the employee stress because of those change interventions. 


\section{REFERENCES}

Abrell-Vogel, C., \& Rowold, J. (2014). Leaders' commitment to change and their effectiveness in change - a multilevel investigation. Journal of Organizational Change Management, 27(6), pp. 900-921. doi:10.1108 /JOCM-07-2012-0111.

Aladwan, K., Bhanugopan, R., \& Fish, A. (2014). Human resource management practices among frontline employees in the Jordanian organizations: navigating through the crossroads of change and challenge. International Journal of Commerce and Management, 24(1), pp. 6-24. doi:10.1108/IJCoMA-09-2011-0027.

Bhatnagar, J., Budhwar, P., Srivastava, P., \& Saini, D. S. (2010). Organizational change and development in India: a case of strategic organizational change and transformation. Journal of Organizational Change Management, 23(5), pp. 485-499.

doi:10.1108/09534811011071243.

Björklund, M. (2010). Linking strategic logistics change to labor rights. Social Responsibility Journal, 6(4), 580-592. doi:10.1108/17471111011083455.

Bull, M., \& Brown, T. (2012). Change communication: the impact on satisfaction with alternative workplace strategies. Facilities, 30(3/4), pp. 135-151. doi:10.1108/02632771211202842.

Perrott, B. E. (2011). Strategic issue management as change catalyst. Strategy \& Leadership, 39(5), pp. 20-29. doi:10.1108/10878571111161499.

Carlström, E. D. (2012). Strategies for change: adaptation to new accounting conditions. Journal of Accounting and Organizational Change, 8(1), 41-61. doi:10.1108/18325911211205739.

Chen, Y., Friedman, R., \& Simons, T. (2014). The gendered trickle-down effect: how mid-level managers' satisfaction with senior managers' supervision affects line employee's turnover intentions. Career Development International, 19(7), pp. 836-856. doi:10.1108/CDI-02-20140031.

Christiansen, J. K., \& Claus, J. V. (2015). Drivers of change in product development rules: how generations of rules change back and forth. European Journal of Innovation Management, 18(2), pp. 218-237. doi:10.1108/EJIM-08-2013-0086.

Cummings, T., \& Worley, C. (2014). Organization development and change. Cengage learning. Cummings, T., \& Worley, C. (2009). Organization development and change. 2009, 2005 SouthWestern, a part of Cengage Learning, p.2.

Davenport, T. H., Harris, J. G., \& Cantrell, S. (2004). Enterprise systems and ongoing process change. Business Process Management Journal, 10(1), pp. 16-26. doi:10.1108/14637150410518301.

Dysvik, A., \& Kuvaas, B. (2010). Exploring the relative and combined influence of masteryapproach goals and work intrinsic motivation on employee turnover intention. Personnel Review, 39(5), pp. 622-638. doi:10.1108/00483481011064172.

Enshassi, A., El-Rayyes, Y., \& Alkilani, S. (2015). Job stress, job burnout and safety performance in the Palestinian construction industry. Journal of Financial Management of Property and Construction, 20 (2), pp. 170-187. doi:10.1108/JFMPC-01-2015-0004.

Farler, L., \& Broady, P. J. (2012). Workplace stress in libraries: a case study. ASLIB Proceedings, 64(3), 225-240. doi:10.1108/00012531211244509.

Ghosh, P., Satyawadi, R., Joshi, J. P., \& Shadman, M. (2013). Who stays with you? Factors predicting employees' intention to stay. International Journal of Organizational Analysis, 21(3), 288-312. doi:10.1108/IJOA-Sep-2011-0511. 
Hede, A. (2010). The dynamics of mindfulness in managing emotions and stress. Journal of Management Development, 29(1), 94-110. doi:10.1108/02621711011009090.

Johannsdottir, L., Olafsson, S., \& Davidsdottir, B. (2015). Leadership role and employee acceptance of change: implementing environmental sustainability strategies within Nordic insurance companies. Journal of Organizational Change Management, 28(1), 72-96. doi:10.1108/JOCM-12-2013-0238.

Krell, E. (2012). Change within (managing change within the human resources function). Human Resource Management International Digest, 20 (1). doi:10.1108/hrmid.2012.04420aaa.013.

Li, X., \& Zhou, E. (2013). Influence of customer verbal aggression on employee turnover intention. Management Decision, 51(4), pp. 890-912. doi:10.1108/00251741311326635.

Magyar, S.V; 2003."Preventing Workplace Violence.” Occupational Health and Safety 72(6), p. 64.

Nguyen, L. D., Boehmer, T., \& Mujtaba, B. G. (2012). Leadership and stress orientations of Germans: an examination based on gender, age, and government work experience. Public Organization Review, 12(4), pp. 401-420.

Nyström, M. E., Höög, E., Garvare, R., Weinehall, L., \& Ivarsson, A. (2013). Change and learning strategies in large scale change programs: describing the variation of strategies used in a health promotion program. Journal of Organizational Change Management, 26(6), pp. 1020-1044. doi:10.1108/JOCM-08-2012-0132.

Oreg, S., (2003). Resistance to Change: Developing an Individual Differences Measure. Journal of Applied Psychology 2003 Vol. 88 (4), pp. 680-693.

Rahman, W., \& Nas, Z. (2013). Employee development and turnover intention: theory validation. European Journal of Training and. Development, 37(6), pp. 564-579.

Raza, M.,A.; Khan, M.,M.; Mujtaba, B., G.; (2017). The Impact of Organizational Change on Employee Turnover Intention: Does Stress Play a Mediating Role?. Springer Science+Business Media New York.

Riot, E., \& de la Burgade, E. (2012). Stamping La poste: an illustration of the influence of societal effects on strategic change. Journal of Strategy and Management, 5(2), 175-210. doi:10.1108/17554251211222893.

Ronnenberg, S., Graham, M. and Mahmoodi, F. (2011), The important role of change management in environmental management system implementation, International Journal of Operations \& Production Management, Vol. 31(6), pp. 631-647.

https://doi.org/10.1108/01443571111131971.

Rothwell, W.; Stavros; J.,M.; Sullivan, R., L.; (2016). Practicing Organization Development: Leading Transformation and Change, Edition: Fourth, Chapter: Chapter 1: Organization Development, Transformation and Change, Publisher: John Wiley and Sons. doi: 10.1002/9781119176626.ch1.

Rusly, F. H., Corner, J. L., \& Sun, P. (2012). Positioning change readiness in knowledge management research. Journal of Knowledge Management, 16(2), pp. 329-355. doi:10.1108/13673271211218906.

Sikdar, A.; Payyazhi, J.; (2014). A process model of managing organizational change during business process redesign. Business Process Management Journal, 20 (6), pp. 971-998. doi:10.1108/BPMJ-02-20130020.

Simoes, P. M. M., \& Esposito, M. (2014). Improving change management: how communication nature influences resistance to change. Journal of Management Development, 33(4), pp. 324-341. doi:10.1108/JMD-05-2012-0058. 
Slåtten, T., Svensson, G., \& Sværi, S. (2011). Service quality and turnover intentions as perceived by employees: antecedents and consequences. Personnel Review, 40(2), 205-221. doi: $10.1108 / 00483481111106084$.

Smollan, R. K. (2015). Causes of stress before, during and after organizational change: a qualitative study. Journal of Organizational Change Management, 28(2), pp. 301-314. doi:10.1108/JOCM-03-2014-0055.

Stensaker, B., Frølich, N., Huisman, J., Waagene, E., Scordato, L., \& Bótas, P. P. (2014). Factors affecting strategic change in higher education. Journal of Strategy and Management, 7(2), pp. 193-207. doi:10.1108/JSMA-12-2012-0066.

Strutton, D., \& Tran, G. A. (2014). How to convert bad stress into good. Management Research Review, 37(12), 1093-1109. doi:10.1108/MRR-06-2013-0139.

Szabla, D.B., Stefanchin, J.E., Warner, L.S. (2014). Connecting Organizational Change Content with Change Strategy: Has Theory Become Practice? In Research in Organizational Change and Development, Vol. 22, pp. 99-140).

Emerald Group Publishing Limited. Retrieved from http://www.emeraldinsight. com/doi/full/10.1108/S0897-301620140000022004.

Thunman, E. (2015). Managing stress: a matter of proactivity or trust? A thematic study of femaleand maledominate Swedish work settings. Qualitative Research in Organizations and Management: An International Journal, 10(2), 134-152. doi:10.1108/QROM-11-2013-1184.

Tjemkes, B., \& Furrer, O. (2010). The antecedents of response strategies in strategic alliances. Management Decision, 48(7), 1103-1133. doi:10.1108/00251741011068806.

Tsai, C., \& Tien, C. (2011). Does organizational strategic fit in supply chain relations affect the propensity for strategic change?: evidence from Taiwanese investments in China. Chinese Management Studies, 5(2), pp. 164-180.

doi:10.1108/17506141111142807.

Tuzun, I. K., \& Kalemci, R. A. (2012). Organizational and supervisory support in relation to employee turnover intentions. Journal of Managerial Psychology, 27(5), pp. 518-534. doi:10.1108/02683941211235418.

Van Hoek, R., Mark, J., Janet, G., \& Andy, B. (2010). Changing chains: three case studies of the change management needed to reconfigure European supply chains. The International Journal of Logistics Management, 21(2), pp. 230-250.

doi:10.1108/09574091011071933.

Vithessonthi, C., \& Thoumrungroje, A. (2011). Strategic change and firm performance: the moderating effect of organisational learning. Journal of Asia Business Studies, 5(2), 194-210. doi:10.1108/15587891111152348.

Wang, E. S.-T. (2014). The effects of relationship bonds on emotional exhaustion and turnover intentions in frontline employees. Journal of Services Marketing, 28(4), pp. 319-330. doi:10.1108/JSM-11-2012-0217.

Wong, Y.,Wong, Y.-W., \&Wong, C. (2015). An integrative model of turnover intention: antecedents and their effects on employee performance in Chinese joint ventures. Journal of Chinese Human Resources Management, 6(1), 71-90. doi:10.1108/JCHRM-06-2014-0015.

Worch, H., Kabinga, M., Eberhard, A., \& Truffer, B. (2012). Strategic renewal and the change of capabilities in utility firms. European Business Review, 24(5), pp. 444-464. doi:10.1108/09555341211254526. 
Yuan, L., Yu, Y., Li, J., \& Ning, L. (2014). Occupational commitment, industrial relations and turnover intention: empirical evidence from China. Chinese Management Studies, 8(1), 66-84. doi:10.1108/CMS- 08-2011-0065. 